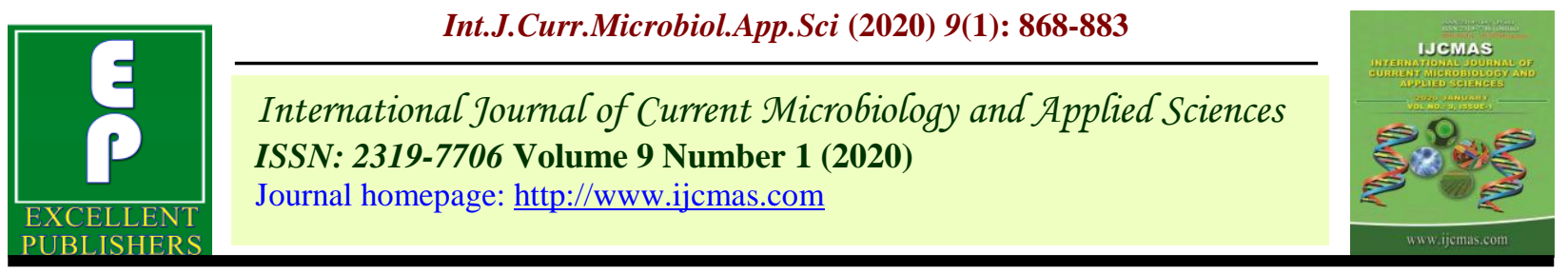

Original Research Article

https://doi.org/10.20546/ijcmas.2020.901.097

\title{
Comparative Study of Personality among Youth in Punjab and Tamilnadu
}

\author{
Sundharalingam Balasubramani* and Tejpreet K. Kang \\ Department of Human Development and Family Studies, \\ Punjab Agricultural University, Ludhiana - 141 004, Punjab, India \\ *Corresponding author
}

Keywords

Personality,

Agreeableness,

Openness,

Extraversion, Youth

Article Info

Accepted:

15 December 2019

Available Online:

20 January 2020

\section{A B S T R A C T}

The present study entitled "Comparative study of personality among youth in Punjab and Tamil Nadu" was undertaken to assess and compare the personality among youth in everyday life in both states. The sample comprised of 300 young adults, 150 Punjab (75 females and 75 males), 150 Tamil Nadu (75 females and 75 males) aged between 18-20 years studying in Punjab Agricultural University (PAU), Ludhiana and Tamil Nadu Agricultural University (TNAU), Coimbatore. The results revealed that the mean scores of agreeableness character of personality showed a significant difference in at medium and high level in both the states was observed. However, in the case of openness, significant differences were found only at high level. The mean scores for extraversion, agreeableness and openness showed significant differences in youth of both the states.

\section{Introduction}

Roberts (2006) defines personality as: "important and relatively stable characteristics within a person that account for consistent patterns of behavior. Aspects of personality may be observable or unobservable, and conscious or unconscious". Alternatively, personality could be described as "a person's general style of interacting with the world, especially with other people". 'Trait' could be defined as "a relatively stable predisposition to behave in a certain way"; the purpose of trait theory is to identify a set of distinct personality dimensions on which psychological differences among individuals could be summarized (Gray 2004). Allport and Odbert (1936) conducted a study based on an English dictionary and found almost 18,000 terms by which human behavior could be described. They identified four major categories, namely: 1) 'personality traits', 2) 'temporary states, moods, and activities', 3) 'highly evaluative judgement of conduct and reputation', and 4) 'physical characteristics, capacities, and talents'. John et al., (2008) made the distinction among (prototypical) traits, states, and activities. The difference 
between traits and states is that traits are stable and enduring, while states are temporary and brief.

Gray (2004) reported that to some degree, traits and states are related to each other: trait could be seen as one's enduring likelihood "of entering temporarily into a particular state". That the focus is on personality from a trait perspective, does not mean that there are no other theoretical perspectives on personality. The purpose of trait theory is to describe schematically human psychological differences and to reveal their impact. However, trait theory does not focus on the internal mental processes that precede people's behaviour; this is done by other theoretical perspectives.

Costa and McCrae (1992) examined the trait theory within personality psychology, where individuals and their unique qualities are distinguished based on descriptions of different universal traits, is a common perspective on human personality. Generally, a trait is understood as "a particular quality in your personality" (Oxford Learner's Dictionaries 2010). The more established technical definition of a personality trait is that it resembles the differences between individual's frequency and intensity of thinking, behaving and feeling in certain ways (Fleeson and Gallagher, 2009; McAdams and Pals, 2006).

Even though, different researchers emphasize different aspects in defining traits. McCrae and Costa (1999) for example, focused on the genotypic bases of traits, including cognitions and affects seen as covert expressions of the traits, whereas Goldberg (1993) focuses on the phenotypical bases of traits, being overt observable behaviours. PytlikZillig et al., (2002) stated that there is a considerable agreement that traits can be defined as patterns of behaviour, motivation, emotion and cognition which are relatively stable in an individual not specific to a certain kind of social milieu or culture. It is well known that there is a correlation between our personality and the way we behave (DeYoung 2010; McCrae and Costa 1999).

McLeod (2014) studied the trait theory of personality suggests that individual differences based on the genetic predisposition form our personality traits. Allport (1955), one of the pioneers of trait theorist, believed that personality is the characteristics of a person that are unique to the individual and that are influenced by both genetically and environmentally, resulting as a behavior in a certain way (Boundless 2016). Additionally, social learning theory connects the personality traits to behaviour, suggesting that behavior is the manifestation of our personality traits (Sarah 2012).

According to Rice (1981) him humanity itself is a poise: for a human being cannot be used merely as means by any human being on the other hand always be used at the same time as an end. It is just in this that this poise part of personality lies, by which he raises himself above all other beings in the world that are not human beings and yet can be used, and so over all things. Cultural misperception with shifting principles, insolences, moralities, and ideals results in pressure, struggle, and temperament disruption in the lives of young people. The parent-child affiliation, social anticipation, perceptual aptitude and cognitive association, with maturational advances in biosocial proficiency and goal structure, in turn, has an important influence on all the latter features of ego improvement.

As per Freud (1964) the nature of integrity a deviations change with personality since its entire elements psychological practices undergo developmental amendment. Intellectual progress affects the generality, 
reliability and abstract quality of moral tenets and refines the self-critical faculty. The flaring of the social prospect and various shifts in adherence and dependency modify values, the basis on which moral onus is persistent (Rice 1981).

Bono and Judge (2004) described the broad personality dimensions that make up the Five Factor model are Extraversion, Neuroticism, Openness to Experience, Agreeableness, and Conscientiousness. Merriam-Webster's dictionary defines Extraversion as the act, state or habit of being predominantly concerned with and obtaining gratification from what is outside the self. These individuals tend to thrive on social attention and to be talkative, active, and energetic.

Depue and Collins (1999) suggested that extraversion is predominately made up of two characteristics. The first is interpersonal engagement, which means valuing relationships with others and intimacy. The second is agency, which is the drive to be socially dominant and to attain leadership positions. Individuals who are high in interpersonal engagement and low in agency are likely to value close relationships without feeling a drive to be in charge of them.

Judge et al., (2002) found that individuals high in agency but low in interpersonal engagement are likely to attempt to dominate social situations but may be unconcerned with the emotions of others in the group. Neurotic individuals tend to view the world negatively. There is a strong association between high Neuroticism and both low self-esteem and low self-efficacy. High Neuroticism is also associated with anxiety, self-doubt, and feelings of uneasiness. This scale, sometimes referred to as emotional instability, or reverse scored as emotional stability, attempts to assess how individuals manage stress.
According to McCrae and John (1992) while individuals who are low in Neuroticism are not necessarily mentally healthy, they are less susceptible to the effects of stress than their peers. Openness to Experience is a general appreciation for art and adventure. Individuals high in Openness to Experience tend to value a variety of novel experiences, be more likely to consider unusual ideas, and be more likely to "think outside the box." Individuals who are low in Openness to Experience tend to approach problems from traditional points of view.

McCrae and Costa (1985) explained that this domain is sometimes called intellect; however the validity of this term is questionable, because a high score in Openness to Experience is only mildly correlated with high levels of intelligence as assessed by prominent measures of intelligence. This domain, more accurately, is defined by the tendency to think creatively rather than the ability to learn and process information quickly. While one might argue this as being linked to intelligence, it seems likely that it is more closely related to mental flexibility than to the overarching concept of IQ as it is currently understood.

As per Graziano and Tobin (2002) agreeableness is defined as a tendency for individuals to cooperate with those around them. These individuals are inclined to be helpful and to value collaboration. Agreeableness is the least well understood of the Big Five domains. They define Agreeableness as the motivation to maintain positive relationships. High levels of Agreeableness are predictive of efforts to avoid conflict and to maintain group cooperation.

Digman and Takemoto-Chock (1981) reported that there are two different conceptualizations of what Conscientiousness 
represents. Conscientiousness is viewed by some personality theorists as the tendency to set and work towards specific goals. These individuals tend to plan to reach their goals and then to execute these plans successfully. According to Tellegen (1982), the second theorized component is the ability to inhibit impulsive behaviours that will interfere with the accomplishment of goals.

Point out factors has been studied by Bem and Allen (1974) found to be adequately stable in self-report data across the lifespan of individuals. However, they have not led to high predictability of behavior across situations. This variability in behavior across situations has become known as the "personality paradox" (Mischel and Shoda, 1995). This has caused a debate about which factor is more important, situation or personality. The debate, at this point, is largely a straw man. Though the notion of a debate between these concepts makes for interesting discussion, experts in the field of personality now recognize that these components are interactional rather than dichotomous (Funder 2006).

Funder et al., (2000) conducted a study which elegantly illuminates this interaction. In this study two opposite-sex individuals were brought into a room and asked to have a conversation. The initial conversation was evaluated using an early version of the Riverside Behavioral Q-sort. This version of the Q-sort, which is made up of 62 items meant to capture general characteristics of socialization, was rated by four research assistants, whose responses were then averaged. This protocol was then repeated, matching the same individuals with different opposite-sex conversation partners for the second Q-sort. These situations were identical in all ways other than each individual having a new conversation partner and having experienced this situation once before. The results were that in the second situation, across individuals, significantly less awkwardness and timidity were shown and greater social skills were exhibited. It was, however, also observed that across individuals, there were significant correlations in the manner in which individuals acted in both situations at the $p<.001$ level for 37 out of the 62 behaviors assessed by the Q-sort. This suggests that while even a slight change in a situation can have a significant effect on behavior, individuals will still maintain their personality characteristics across situations. In other words, though individuals will behave differently in differing situations, they also exhibit consistency in behavior to at least some degree.

American Psychological Association (1981) explicitly mentions "conscience" as an important ethical guide for the psychologist when conducting 'research. Finally, research on the mature personality supports the importance of a private moral self. Blocher (1974) has stated that an autonomous and stable value system is integral to healthy and mature functioning. After reviewing several developmental and personality theorists, he has pointed out that commitment to personal values is an essential component of the "effective personality."

The main objectives of the study include, to study the locale wise differences of personality among youth in both the states. to determine the locale wise differences in female and males of personality in two settings.

\section{Materials and Methods}

The study was conducted in constituent colleges of Punjab Agricultural University, Ludhiana and Tamil Nadu Agricultural University, Coimbatore. The sample comprised of 300 young adults aged between 
18-20 years studying in Punjab Agricultural University, Ludhiana and Tamil Nadu Agricultural University, Coimbatore.

Sample selection from PAU - the schematic presentation of the sample selection. Three colleges that included College of Agriculture, College of Agricultural Engineering and Technology, College of Home Science were purposively selected (College of Basic Sciences and Humanities not selected because, it is not available in TNAU, Coimbatore) . In TNAU colleges selected were Agricultural College and Research Institute, Coimbatore, Agricultural Engineering College and Research Institute, Coimbatore and Community Science College and Research Institute, Madurai.

The sample was equally distributed across both the gender. Total of 300 sample students were randomly selected and surveyed. The sample of both the genders was such drawn that it equally represents the three sociocultural zones of Punjab and Tamil Nadu. In Punjab regions included Malwa, Majha and Doaba whereas in Tamil Nadu the selected regions East zone, West zone, North zone, and South zone. Respondent's socio-cultural zones details were collected from their respective College Dean's Office.

Tools for data collection - big five inventory by John and Srivastava (1999)

The personality pattern of the respondents was assessed by Big Five Inventory by John and Srivastava (1999). The inventory contained 44 items and it measured personality in five dimensions which are Extraversion Vs Introversion, Agreeableness Vs Antagonism, Conscientiousness Vs Lack of Direction, Neuroticism Vs Emotional Stability and Openness Vs Closedness to experience.

\section{Results and Discussion} Local-wise gender distribution of youth
across different dimensions of personality

The comparison of personality among youth in Punjab and Tamil Nadu was presented inTable 1. displays distribution of Punjab and Tamil Nadu youth across different dimensions of personality. Non-significant difference was observed among females and males of Punjab in all the three levels of dimensions of personality. Tamil Nadu females show significant differences in low level of neuroticism feature of personality. Other dimensions of personality had non-significant difference in all the levels among females and males of Tamil Nadu. With regard to total sample, Tamil Nadu and Punjab youth shows significant differences in medium and high level of agreeable dimension, respectively. Punjab youth also had significant difference in high level of openness dimension of personality. Non-significant difference existed for extraversion, conscientiousness and neuroticism in all the levels of personality dimensions in the total sample. According to Graziano and Tobin (2002) agreeableness is defined as a tendency for individuals to cooperate with those around them. These individuals are inclined to be helpful and to value collaboration. Agreeableness is the least well understood of the Big Five domains. They define agreeableness as the motivation to maintain positive relationships. High levels of agreeableness are predictive of efforts to avoid conflict and to maintain group cooperation.

\section{Locale-wise distribution of the Punjab and Tamil Nadu females across different dimensions of personality}

Locale-wise distribution of the Punjab and Tamil Nadu females across different dimensions of personality was presented in 
Table 2 represents locale-wise distribution of the Punjab and Tamil Nadu females across different dimensions of personality. Significant differences existed among rural females of Punjab in high level of extraversion dimension of personality. Neuroticism in low and medium levels shows significant differences among urban and rural females of Punjab, respectively.

Urban females of Punjab also show significant difference in low level of openness dimension. Significant differences existed in high level of extraversion and openness and low level of conscientiousness dimensions among urban females of Tamil Nadu. With regard of total sample, significant differences were found among Tamil Nadu and Punjab females in medium and high levels of agreeableness, respectively. Punjab females displayed significant differences in high level of neuroticism dimension. Non-significant differences were found in extraversion, conscientiousness and openness dimensions of personality in total sample.

\section{Locale-wise distribution of the Punjab and Tamil Nadu males across different dimensions of personality}

Locale-wise distribution of the Punjab and Tamil Nadu males across different dimensions of personality was depicted in Table 3 elucidates locale-wise distribution of the Punjab and Tamil Nadu males across different dimensions of personality. Punjab and Tamil Nadu males shows significant differences in high and medium level of neuroticism dimension, respectively. Other dimensions of personality had non-significant differences in all the levels. In total sample, significant differences were found in medium and high levels of agreeableness dimension among Tamil Nadu and Punjab males, respectively. Openness dimension was also found to be significantly different among
Tamil Nadu and Punjab males in medium and high levels.

Locale-wise gender differences in the mean scores $( \pm \mathrm{SD})$ of the respondents across different dimensions of personality

Locale-wise gender differences in the mean scores $( \pm \mathrm{SD})$ of the respondents across different dimensions of personality was elucidated in Table 4 depicts distribution of mean scores $( \pm \mathrm{SD})$ of the Punjab and Tamil Nadu youth across different dimensions of personality. Non-significant differences were found in all the dimensions of personality among Punjab youth in common. Tamil Nadu males exhibited significantly better scores in neuroticism dimension. Other dimensions of personality had non-significant differences among Tamil Nadu youth. In total sample, Punjab youth displays significantly better scores in extraversion, agreeableness and openness dimensions of the personality.

Locale-wise comparison of mean scores $( \pm$ SD) of the Punjab and Tamil Nadu females across different dimensions of personality

Locale-wise comparison of mean scores $( \pm$ SD) of the Punjab and Tamil Nadu females across different dimensions of personality in Table 5 constitutes locale wise distribution of mean scores $( \pm \mathrm{SD})$ of the Punjab and Tamil Nadu females across different dimensions of personality. In locale distribution, Punjab rural females had significantly better scores in conscientiousness dimension. Whereas, other dimensions show non-significant differences among Punjab rural and urban females. In case of Tamil Nadu females, all dimensions had non-significant relationship in common. Contrastingly, Punjab females had significantly better scores in all the dimensions except for conscientiousness in total sample. 
Table.1 Local-wise gender distribution of youth across different dimensions of personality

\begin{tabular}{|c|c|c|c|c|c|c|c|c|c|c|}
\hline \multirow{3}{*}{$\begin{array}{c}\text { Dimensions } \\
\text { of } \\
\text { personality }\end{array}$} & \multirow[t]{3}{*}{ Levels } & \multicolumn{3}{|c|}{ Punjab $\left(n_{1}=150\right)$} & \multicolumn{3}{|c|}{ Tamil Nadu $\left(n_{2}=150\right)$} & \multicolumn{3}{|c|}{ Total $(n=300)$} \\
\hline & & \multirow{2}{*}{$\begin{array}{c}\text { Females } \\
\text { f } \\
(\%)\end{array}$} & \multirow{2}{*}{$\begin{array}{c}\text { Males } \\
\mathbf{f} \\
(\%)\end{array}$} & \multirow[t]{2}{*}{ Z-value } & \multirow{2}{*}{$\begin{array}{c}\text { Females } \\
\mathbf{f} \\
(\%)\end{array}$} & \multirow{2}{*}{$\begin{array}{c}\text { Males } \\
\mathbf{f} \\
(\%)\end{array}$} & \multirow[t]{2}{*}{ Z-value } & \multirow{2}{*}{$\begin{array}{c}\text { Punjab } \\
\mathbf{f} \\
(\%)\end{array}$} & \multirow{2}{*}{$\begin{array}{c}\text { TN } \\
\mathbf{f} \\
(\%)\end{array}$} & \multirow[t]{2}{*}{ Z-value } \\
\hline & & & & & & & & & & \\
\hline \multirow[t]{3}{*}{ Extraversion } & Low & $\begin{array}{c}3 \\
(4.00)\end{array}$ & $\begin{array}{c}1 \\
(1.33)\end{array}$ & 1.014 & $\begin{array}{c}3 \\
(4.00)\end{array}$ & $\begin{array}{c}1 \\
(1.33)\end{array}$ & 0.990 & $\begin{array}{c}4 \\
(2.67)\end{array}$ & $\begin{array}{c}4 \\
(2.67)\end{array}$ & 0.000 \\
\hline & Medium & $\begin{array}{c}56 \\
(74.67)\end{array}$ & $\begin{array}{c}55 \\
(73.33)\end{array}$ & 0.186 & $\begin{array}{c}60 \\
(80.00)\end{array}$ & $\begin{array}{c}62 \\
(82.67)\end{array}$ & 0.341 & $\begin{array}{c}111 \\
(74.00)\end{array}$ & $\begin{array}{c}122 \\
(81.33)\end{array}$ & 1.525 \\
\hline & High & $\begin{array}{c}16 \\
(21.33)\end{array}$ & $\begin{array}{c}19 \\
(25.33)\end{array}$ & 0.579 & $\begin{array}{c}12 \\
(16.00)\end{array}$ & $\begin{array}{c}12 \\
(16.00)\end{array}$ & 0.071 & $\begin{array}{c}35 \\
(23.33)\end{array}$ & $\begin{array}{c}24 \\
(16.00)\end{array}$ & 1.598 \\
\hline \multirow{3}{*}{ Agreeableness } & Low & $\begin{array}{c}0 \\
(0.00)\end{array}$ & $\begin{array}{c}0 \\
(0.00)\end{array}$ & NA & $\begin{array}{c}0 \\
(0.00)\end{array}$ & $\begin{array}{c}1 \\
(1.33)\end{array}$ & 1.010 & $\begin{array}{c}0 \\
(0.00)\end{array}$ & $\begin{array}{c}1 \\
(0.67)\end{array}$ & 1.002 \\
\hline & Medium & $\begin{array}{c}29 \\
(38.67)\end{array}$ & $\begin{array}{c}32 \\
(42.67)\end{array}$ & 0.499 & $\begin{array}{c}41 \\
(54.67)\end{array}$ & $\begin{array}{c}46 \\
(61.33)\end{array}$ & 0.688 & $\begin{array}{c}61 \\
(40.67)\end{array}$ & $\begin{array}{c}87 \\
(58.00)\end{array}$ & $3.002 * *$ \\
\hline & High & $\begin{array}{c}46 \\
(61.33) \\
\end{array}$ & $\begin{array}{c}43 \\
(57.33) \\
\end{array}$ & 0.499 & $\begin{array}{c}34 \\
(45.33)\end{array}$ & $\begin{array}{c}28 \\
(37.33) \\
\end{array}$ & 0.858 & $\begin{array}{c}89 \\
(59.33)\end{array}$ & $\begin{array}{c}62 \\
(41.33)\end{array}$ & 3.118** \\
\hline \multirow{3}{*}{ Conscientiousness } & Low & $\begin{array}{c}4 \\
(5.33)\end{array}$ & $\begin{array}{c}4 \\
(5.33)\end{array}$ & 0.000 & $\begin{array}{c}3 \\
(4.00)\end{array}$ & $\begin{array}{c}1 \\
(1.33)\end{array}$ & 0.990 & $\begin{array}{c}8 \\
(5.33)\end{array}$ & $\begin{array}{c}4 \\
(2.67)\end{array}$ & 1.179 \\
\hline & Medium & $\begin{array}{c}49 \\
(65.33)\end{array}$ & $\begin{array}{c}48 \\
(64.00)\end{array}$ & 0.171 & $\begin{array}{c}51 \\
(68.00)\end{array}$ & $\begin{array}{c}55 \\
(73.33)\end{array}$ & 0.612 & $\begin{array}{c}97 \\
(64.67)\end{array}$ & $\begin{array}{c}106 \\
(70.67)\end{array}$ & 1.111 \\
\hline & High & $\begin{array}{c}22 \\
(29.33)\end{array}$ & $\begin{array}{c}23 \\
(30.67)\end{array}$ & 0.178 & $\begin{array}{c}21 \\
(28.00)\end{array}$ & $\begin{array}{c}19 \\
(25.33)\end{array}$ & 0.271 & $\begin{array}{c}45 \\
(30.00)\end{array}$ & $\begin{array}{c}40 \\
(26.67)\end{array}$ & 0.641 \\
\hline \multirow[t]{3}{*}{ Neuroticism } & Low & $\begin{array}{c}9 \\
(12.00)\end{array}$ & $\begin{array}{c}8 \\
(10.67)\end{array}$ & 0.258 & $\begin{array}{c}12 \\
(16.00)\end{array}$ & $\begin{array}{c}4 \\
(5.33)\end{array}$ & $2.066 *$ & $\begin{array}{c}17 \\
(11.33)\end{array}$ & $\begin{array}{c}16 \\
(10.67)\end{array}$ & 0.185 \\
\hline & Medium & $\begin{array}{c}50 \\
(66.67)\end{array}$ & $\begin{array}{c}51 \\
(68.00)\end{array}$ & 0.174 & $\begin{array}{c}54 \\
(72.00)\end{array}$ & $\begin{array}{c}54 \\
(72.00)\end{array}$ & 0.102 & $\begin{array}{c}101 \\
(67.33)\end{array}$ & $\begin{array}{c}108 \\
(72.00)\end{array}$ & 0.879 \\
\hline & High & $\begin{array}{c}16 \\
(21.33)\end{array}$ & $\begin{array}{c}16 \\
(21.33)\end{array}$ & 0.000 & $\begin{array}{c}9 \\
(12.00)\end{array}$ & $\begin{array}{c}17 \\
(22.67)\end{array}$ & 1.798 & $\begin{array}{c}32 \\
(21.33)\end{array}$ & $\begin{array}{c}26 \\
(17.33)\end{array}$ & 0.877 \\
\hline \multirow[t]{3}{*}{ Openness } & Low & $\begin{array}{c}2 \\
(2.67)\end{array}$ & $\begin{array}{c}1 \\
(1.33)\end{array}$ & 0.583 & $\begin{array}{c}2 \\
(2.67)\end{array}$ & $\begin{array}{c}3 \\
(4.00)\end{array}$ & 0.485 & $\begin{array}{c}3 \\
(2.00)\end{array}$ & $\begin{array}{c}5 \\
(3.33)\end{array}$ & 0.717 \\
\hline & Medium & $\begin{array}{c}50 \\
(66.67)\end{array}$ & $\begin{array}{c}43 \\
(57.33)\end{array}$ & 1.178 & $\begin{array}{c}50 \\
(66.67)\end{array}$ & $\begin{array}{c}57 \\
(76.00)\end{array}$ & 1.161 & $\begin{array}{c}93 \\
(62.00)\end{array}$ & $\begin{array}{c}107 \\
(71.33)\end{array}$ & 1.715 \\
\hline & High & $\begin{array}{c}23 \\
(30.67)\end{array}$ & $\begin{array}{c}31 \\
(41.33)\end{array}$ & 1.361 & $\begin{array}{c}23 \\
(30.67)\end{array}$ & $\begin{array}{c}15 \\
(20.00)\end{array}$ & 1.408 & $\begin{array}{c}54 \\
(36.00)\end{array}$ & $\begin{array}{c}38 \\
(25.33)\end{array}$ & $2.003^{*}$ \\
\hline
\end{tabular}

$*$ Significant at $5 \%$ level, $* *$ Significant at $1 \%$ level 
Table.2 Locale-wise distribution of the Punjab and Tamil Nadu females across different dimensions of personality

\begin{tabular}{|c|c|c|c|c|c|c|c|c|c|c|}
\hline \multirow{3}{*}{$\begin{array}{c}\text { Dimensions } \\
\text { of } \\
\text { personality }\end{array}$} & \multirow[t]{3}{*}{ Levels } & \multicolumn{3}{|c|}{ Punjab females $\left(n_{1}=75\right)$} & \multicolumn{3}{|c|}{ Tamil Nadu females $\left(n_{2}=75\right)$} & \multicolumn{3}{|c|}{ Total $(n=150)$} \\
\hline & & Rural & Urban & Z-value & Rural & Urban & Z-value & $\begin{array}{l}\text { Punjab } \\
\text { females }\end{array}$ & $\begin{array}{c}\text { TN } \\
\text { females }\end{array}$ & Z-value \\
\hline & & $\begin{array}{c}\mathbf{f} \\
(\%)\end{array}$ & $\begin{array}{c}\mathbf{f} \\
(\%)\end{array}$ & & $\begin{array}{c}\mathbf{f} \\
(\%)\end{array}$ & $\begin{array}{c}\mathbf{f} \\
(\%)\end{array}$ & & $\begin{array}{c}\mathbf{f} \\
(\%)\end{array}$ & $\begin{array}{c}\mathbf{f} \\
(\%)\end{array}$ & \\
\hline \multirow[t]{3}{*}{ Extraversion } & Low & $\begin{array}{c}1 \\
(2.86)\end{array}$ & $\begin{array}{c}2 \\
(5.00)\end{array}$ & 0.675 & $\begin{array}{c}2 \\
(4.44)\end{array}$ & $\begin{array}{c}1 \\
(3.33)\end{array}$ & 0.323 & $\begin{array}{c}3 \\
(4.00)\end{array}$ & $\begin{array}{c}3 \\
(4.00)\end{array}$ & 0.000 \\
\hline & Medium & $\begin{array}{c}24 \\
(68.57)\end{array}$ & $\begin{array}{c}32 \\
(80.00)\end{array}$ & 1.601 & $\begin{array}{c}38 \\
(84.44)\end{array}$ & $\begin{array}{c}22 \\
(73.33)\end{array}$ & 1.723 & $\begin{array}{c}56 \\
(74.67)\end{array}$ & $\begin{array}{c}60 \\
(80.000\end{array}$ & 1.103 \\
\hline & High & $\begin{array}{c}10 \\
(28.57)\end{array}$ & $\begin{array}{c}6 \\
(15.00)\end{array}$ & $2.013^{*}$ & $\begin{array}{c}5 \\
(11.11)\end{array}$ & $\begin{array}{c}7 \\
(23.33)\end{array}$ & $2.027 *$ & $\begin{array}{c}16 \\
(21.33)\end{array}$ & $\begin{array}{c}12 \\
(16.00)\end{array}$ & 1.185 \\
\hline \multirow{3}{*}{ Agreeableness } & Low & $\begin{array}{c}0 \\
(0)\end{array}$ & $\begin{array}{c}0 \\
(0)\end{array}$ & NA & $\begin{array}{c}0 \\
(0.00)\end{array}$ & $\begin{array}{c}0 \\
(0)\end{array}$ & NA & $\begin{array}{c}0 \\
(0)\end{array}$ & $\begin{array}{c}0 \\
(0.00)\end{array}$ & NA \\
\hline & Medium & $\begin{array}{c}15 \\
(42.86)\end{array}$ & $\begin{array}{c}14 \\
(35.00)\end{array}$ & 0.987 & $\begin{array}{c}27 \\
(60.00)\end{array}$ & $\begin{array}{c}14 \\
(46.67)\end{array}$ & 1.744 & $\begin{array}{c}29 \\
(38.67)\end{array}$ & $\begin{array}{c}41 \\
(54.67)\end{array}$ & $2.777 * *$ \\
\hline & High & $\begin{array}{c}20 \\
(57.14)\end{array}$ & $\begin{array}{c}26 \\
(65.00)\end{array}$ & 0.987 & $\begin{array}{c}18 \\
(40.00)\end{array}$ & $\begin{array}{c}16 \\
(53.33)\end{array}$ & 1.744 & $\begin{array}{c}46 \\
(61.33)\end{array}$ & $\begin{array}{c}34 \\
(45.33)\end{array}$ & $2.777 * *$ \\
\hline \multirow{3}{*}{ Conscientiousness } & Low & $\begin{array}{c}1 \\
(2.86)\end{array}$ & $\begin{array}{c}3 \\
(7.50)\end{array}$ & 1.283 & $\begin{array}{c}0 \\
(0)\end{array}$ & $\begin{array}{c}3 \\
(10.00)\end{array}$ & $2.810 * *$ & $\begin{array}{c}4 \\
(5.33)\end{array}$ & $\begin{array}{c}3 \\
(4.00)\end{array}$ & 0.547 \\
\hline & Medium & $\begin{array}{c}22 \\
(62.86)\end{array}$ & $\begin{array}{c}27 \\
(67.50)\end{array}$ & 0.597 & $\begin{array}{c}30 \\
(66.67)\end{array}$ & $\begin{array}{c}21 \\
(70.00)\end{array}$ & 0.344 & $\begin{array}{c}49 \\
(65.33)\end{array}$ & $\begin{array}{c}51 \\
(68.00)\end{array}$ & 0.490 \\
\hline & High & $\begin{array}{c}12 \\
(34.29)\end{array}$ & $\begin{array}{c}10 \\
(25.00)\end{array}$ & 1.245 & $\begin{array}{c}15 \\
(33.33)\end{array}$ & $\begin{array}{c}6 \\
(20.00)\end{array}$ & 1.754 & $\begin{array}{c}22 \\
(29.33)\end{array}$ & $\begin{array}{c}21 \\
(28.00)\end{array}$ & 0.255 \\
\hline \multirow[t]{3}{*}{ Neuroticism } & Low & $\begin{array}{c}2 \\
(5.71)\end{array}$ & $\begin{array}{c}7 \\
(17.50)\end{array}$ & $2.253^{*}$ & $\begin{array}{c}8 \\
(17.78)\end{array}$ & $\begin{array}{c}4 \\
(13.33)\end{array}$ & 0.689 & $\begin{array}{c}9 \\
(12.00)\end{array}$ & $\begin{array}{c}12 \\
(16.00)\end{array}$ & 0.998 \\
\hline & Medium & $\begin{array}{c}27 \\
(77.14)\end{array}$ & $\begin{array}{c}23 \\
(57.50)\end{array}$ & $2.565^{*}$ & $\begin{array}{c}31 \\
(68.89)\end{array}$ & $\begin{array}{c}23 \\
(76.67)\end{array}$ & 0.981 & $\begin{array}{c}50 \\
(66.67)\end{array}$ & $\begin{array}{c}54 \\
(72.00)\end{array}$ & 1.002 \\
\hline & High & $\begin{array}{c}6 \\
(17.14)\end{array}$ & $\begin{array}{c}10 \\
(25.00)\end{array}$ & 1.180 & $\begin{array}{c}6 \\
(13.33)\end{array}$ & $\begin{array}{c}3 \\
(10.00)\end{array}$ & 0.584 & $\begin{array}{c}16 \\
(21.33)\end{array}$ & $\begin{array}{c}9 \\
(12.00)\end{array}$ & 2.169* \\
\hline \multirow[t]{3}{*}{ Openness } & Low & $\begin{array}{c}0 \\
(0)\end{array}$ & $\begin{array}{c}2 \\
(5.00)\end{array}$ & $1.961 *$ & $\begin{array}{c}2 \\
(4.44)\end{array}$ & $\begin{array}{c}0 \\
(0)\end{array}$ & 1.826 & $\begin{array}{c}2 \\
(2.67)\end{array}$ & $\begin{array}{c}2 \\
(2.67)\end{array}$ & 0.000 \\
\hline & Medium & $\begin{array}{c}23 \\
(65.71)\end{array}$ & $\begin{array}{c}27 \\
(67.50)\end{array}$ & 0.232 & $\begin{array}{c}32 \\
(71.11)\end{array}$ & $\begin{array}{c}18 \\
(60.00)\end{array}$ & 1.516 & $\begin{array}{c}50 \\
(66.67)\end{array}$ & $\begin{array}{c}50 \\
(66.67)\end{array}$ & 0.000 \\
\hline & High & $\begin{array}{c}12 \\
(34.29)\end{array}$ & $\begin{array}{c}11 \\
(27.50)\end{array}$ & 0.899 & $\begin{array}{c}11 \\
(24.44)\end{array}$ & $\begin{array}{c}12 \\
(40.00)\end{array}$ & $2.113^{*}$ & $\begin{array}{c}23 \\
(30.67)\end{array}$ & $\begin{array}{c}23 \\
(30.67)\end{array}$ & 0.000 \\
\hline
\end{tabular}

*Significant at $5 \%$ level, ** Significant at $1 \%$ level 
Table.3 Locale-wise distribution of the Punjab and Tamil Nadu males across different dimensions of personality

\begin{tabular}{|c|c|c|c|c|c|c|c|c|c|c|}
\hline \multirow{3}{*}{$\begin{array}{c}\text { Dimensions } \\
\text { of personality }\end{array}$} & \multirow[t]{3}{*}{ Levels } & \multicolumn{3}{|c|}{ Punjab males $\left(n_{1}=75\right)$} & \multicolumn{3}{|c|}{ Tamil Nadu males $\left(n_{2}=75\right)$} & \multicolumn{3}{|c|}{ Total $(n=150)$} \\
\hline & & \multirow{2}{*}{$\begin{array}{c}\text { Rural } \\
\mathbf{f} \\
(\%)\end{array}$} & \multirow{2}{*}{$\begin{array}{c}\text { Urban } \\
\text { f } \\
(\%)\end{array}$} & \multirow[t]{2}{*}{ Z-value } & \multirow{2}{*}{$\begin{array}{c}\text { Rural } \\
\text { f } \\
(\%)\end{array}$} & \multirow{2}{*}{$\begin{array}{c}\text { Urban } \\
\mathbf{f} \\
(\%)\end{array}$} & \multirow[t]{2}{*}{ Z-value } & \multirow{2}{*}{$\begin{array}{c}\text { Punjab males } \\
\text { f } \\
(\%)\end{array}$} & \multirow{2}{*}{$\begin{array}{c}\text { TN males } \\
\mathbf{f} \\
(\%)\end{array}$} & \multirow[t]{2}{*}{ Z-value } \\
\hline & & & & & & & & & & \\
\hline \multirow[t]{3}{*}{ Extraversion } & Low & $\begin{array}{c}0 \\
(0)\end{array}$ & $\begin{array}{c}1 \\
(2.17)\end{array}$ & 1.284 & $\begin{array}{c}0 \\
(0)\end{array}$ & $\begin{array}{c}1 \\
(2.50)\end{array}$ & 1.396 & $\begin{array}{c}1 \\
(1.33)\end{array}$ & $\begin{array}{c}1 \\
(1.33)\end{array}$ & 0.000 \\
\hline & Medium & $\begin{array}{c}21 \\
(72.41)\end{array}$ & $\begin{array}{c}34 \\
(73.91)\end{array}$ & 0.207 & $\begin{array}{c}29 \\
(82.86)\end{array}$ & $\begin{array}{c}33 \\
(82.50)\end{array}$ & 0.130 & $\begin{array}{c}55 \\
(73.33)\end{array}$ & $\begin{array}{c}62 \\
(82.67)\end{array}$ & 1.951 \\
\hline & High & $\begin{array}{c}8 \\
(27.59)\end{array}$ & $\begin{array}{c}11 \\
(23.91)\end{array}$ & 0.514 & $\begin{array}{c}6 \\
(17.14)\end{array}$ & $\begin{array}{c}6 \\
(15.00)\end{array}$ & 0.292 & $\begin{array}{c}19 \\
(25.33)\end{array}$ & $\begin{array}{c}12 \\
(16.00)\end{array}$ & $1.996 *$ \\
\hline \multirow{3}{*}{ Agreeableness } & Low & $\begin{array}{c}0 \\
(0)\end{array}$ & $\begin{array}{c}0 \\
(0)\end{array}$ & NA & $\begin{array}{c}0 \\
(0)\end{array}$ & $\begin{array}{c}1 \\
(2.50)\end{array}$ & 1.396 & $\begin{array}{c}0 \\
(0)\end{array}$ & $\begin{array}{c}1 \\
(1.33)\end{array}$ & 1.419 \\
\hline & Medium & $\begin{array}{c}11 \\
(37.93)\end{array}$ & $\begin{array}{c}21 \\
(45.65)\end{array}$ & 0.959 & $\begin{array}{c}22 \\
(62.86)\end{array}$ & $\begin{array}{c}24 \\
(60.00)\end{array}$ & 0.487 & $\begin{array}{c}32 \\
(42.67)\end{array}$ & $\begin{array}{c}46 \\
(61.33)\end{array}$ & $3.236 * *$ \\
\hline & High & $\begin{array}{c}18 \\
(62.07) \\
\end{array}$ & $\begin{array}{c}25 \\
(54.35)\end{array}$ & 0.959 & $\begin{array}{c}13 \\
(37.14)\end{array}$ & $\begin{array}{c}15 \\
(37.50)\end{array}$ & 0.167 & $\begin{array}{c}43 \\
(57.33) \\
\end{array}$ & $\begin{array}{c}28 \\
(37.33)\end{array}$ & $3.469 * *$ \\
\hline \multirow{3}{*}{ Conscientiousness } & Low & $\begin{array}{c}1 \\
(3.45)\end{array}$ & $\begin{array}{c}3 \\
(6.52)\end{array}$ & 0.865 & $\begin{array}{c}0 \\
(0)\end{array}$ & $\begin{array}{c}1 \\
(2.50)\end{array}$ & 1.396 & $\begin{array}{c}4 \\
(5.33)\end{array}$ & $\begin{array}{c}1 \\
(1.33)\end{array}$ & 1.930 \\
\hline & Medium & $\begin{array}{c}17 \\
(58.62)\end{array}$ & $\begin{array}{c}31 \\
(67.39)\end{array}$ & 1.112 & $\begin{array}{c}26 \\
(74.29)\end{array}$ & $\begin{array}{c}29 \\
(72.50)\end{array}$ & 0.344 & $\begin{array}{c}48 \\
(64.00)\end{array}$ & $\begin{array}{c}55 \\
(73.33)\end{array}$ & 1.743 \\
\hline & High & $\begin{array}{c}11 \\
(37.93)\end{array}$ & $\begin{array}{c}12 \\
(26.09)\end{array}$ & 1.555 & $\begin{array}{c}9 \\
(25.71)\end{array}$ & $\begin{array}{c}10 \\
(25.00)\end{array}$ & 0.010 & $\begin{array}{c}23 \\
(30.67)\end{array}$ & $\begin{array}{c}19 \\
(25.33)\end{array}$ & 1.029 \\
\hline \multirow[t]{3}{*}{ Neuroticism } & Low & $\begin{array}{c}4 \\
(13.79)\end{array}$ & $\begin{array}{c}4 \\
(8.70)\end{array}$ & 0.988 & $\begin{array}{c}1 \\
(2.86)\end{array}$ & $\begin{array}{c}3 \\
(7.50)\end{array}$ & 1.325 & $\begin{array}{c}8 \\
(10.67)\end{array}$ & $\begin{array}{c}4 \\
(5.33)\end{array}$ & 1.703 \\
\hline & Medium & $\begin{array}{c}22 \\
(75.86)\end{array}$ & $\begin{array}{c}29 \\
(63.04)\end{array}$ & 1.704 & $\begin{array}{c}28 \\
(80.00)\end{array}$ & $\begin{array}{c}26 \\
(65.00)\end{array}$ & $2.169 *$ & $\begin{array}{c}51 \\
(68.00)\end{array}$ & $\begin{array}{c}54 \\
(72.00)\end{array}$ & 0.756 \\
\hline & High & $\begin{array}{c}3 \\
(10.34)\end{array}$ & $\begin{array}{c}13 \\
(28.26)\end{array}$ & $2.780 * *$ & $\begin{array}{c}6 \\
(17.14)\end{array}$ & $\begin{array}{c}11 \\
(27.50)\end{array}$ & 1.618 & $\begin{array}{c}16 \\
(21.33)\end{array}$ & $\begin{array}{c}17 \\
(22.67)\end{array}$ & 0.279 \\
\hline \multirow[t]{3}{*}{ Openness } & Low & $\begin{array}{c}0 \\
(0)\end{array}$ & $\begin{array}{c}1 \\
(2.17)\end{array}$ & 1.284 & $\begin{array}{c}1 \\
(2.86)\end{array}$ & $\begin{array}{c}2 \\
(5.00)\end{array}$ & 0.710 & $\begin{array}{c}1 \\
(1.33)\end{array}$ & $\begin{array}{c}3 \\
(4.00)\end{array}$ & 1.433 \\
\hline & Medium & $\begin{array}{c}18 \\
(62.07)\end{array}$ & $\begin{array}{c}25 \\
(54.35)\end{array}$ & 0.959 & $\begin{array}{c}28 \\
(80.00)\end{array}$ & $\begin{array}{c}29 \\
(72.50)\end{array}$ & 1.175 & $\begin{array}{c}43 \\
(57.33)\end{array}$ & $\begin{array}{c}57 \\
(76.00)\end{array}$ & $3.429 * *$ \\
\hline & High & $\begin{array}{c}11 \\
(37.93)\end{array}$ & $\begin{array}{c}20 \\
(43.48)\end{array}$ & 0.691 & $\begin{array}{c}6 \\
(17.14)\end{array}$ & $\begin{array}{c}9 \\
(22.50)\end{array}$ & 0.907 & $\begin{array}{c}31 \\
(41.33)\end{array}$ & $\begin{array}{c}15 \\
(20.00)\end{array}$ & $4.007 * *$ \\
\hline
\end{tabular}

*Significant at $5 \%$ level ,** Significant at $1 \%$ level 
Table.4 Locale-wise gender differences in the mean scores $( \pm \mathrm{SD})$ of the respondents across different dimensions of personality

\begin{tabular}{|c|c|c|c|c|c|c|c|c|c|}
\hline \multirow{3}{*}{$\begin{array}{c}\text { Dimensions } \\
\text { of } \\
\text { personality }\end{array}$} & \multicolumn{3}{|c|}{ Punjab $\left(n_{1}=150\right)$} & \multicolumn{3}{|c|}{ Tamil Nadu $\left(n_{2}=150\right)$} & \multicolumn{3}{|c|}{ Total $(n=300)$} \\
\hline & Females & Males & \multirow{2}{*}{$\begin{array}{c}\text { t- } \\
\text { value }\end{array}$} & Females & Males & \multirow[b]{2}{*}{$\begin{array}{c}\text { t- } \\
\text { value }\end{array}$} & Punjab & $\mathbf{T N}$ & \multirow[t]{2}{*}{ t- value } \\
\hline & $\begin{array}{l}\text { mean } \\
( \pm \text { SD })\end{array}$ & $\begin{array}{l}\text { mean } \\
( \pm \mathrm{SD})\end{array}$ & & $\begin{array}{l}\text { mean } \\
( \pm \text { SD })\end{array}$ & $\begin{array}{l}\text { mean } \\
( \pm S D)\end{array}$ & & $\begin{array}{l}\text { mean } \\
( \pm \mathrm{SD})\end{array}$ & $\begin{array}{l}\text { mean } \\
( \pm \text { SD })\end{array}$ & \\
\hline Extraversion & $\begin{array}{c}26.96 \\
( \pm 5.05)\end{array}$ & $\begin{array}{c}27.32 \\
( \pm 4.79)\end{array}$ & 0.448 & $\begin{array}{c}25.43 \\
( \pm 4.31)\end{array}$ & $\begin{array}{c}26.12 \\
( \pm 3.81)\end{array}$ & 1.035 & $\begin{array}{c}27.14 \\
( \pm 4.91)\end{array}$ & $\begin{array}{c}25.77 \\
( \pm 4.07)\end{array}$ & $2.623 *$ \\
\hline Agreeableness & $\begin{array}{c}33.87 \\
( \pm 4.20)\end{array}$ & $\begin{array}{c}33.67 \\
( \pm 4.06)\end{array}$ & 0.296 & $\begin{array}{c}32.13 \\
( \pm 5.31)\end{array}$ & $\begin{array}{c}30.70 \\
( \pm 5.79)\end{array}$ & 1.575 & $\begin{array}{c}33.77 \\
( \pm 4.12)\end{array}$ & $\begin{array}{c}31.43 \\
( \pm 5.58)\end{array}$ & $4.132 * *$ \\
\hline Conscientiousness & $\begin{array}{c}29.44 \\
( \pm 5.30)\end{array}$ & $\begin{array}{c}29.79 \\
( \pm 5.72)\end{array}$ & 0.385 & $\begin{array}{c}29.72 \\
( \pm 5.07)\end{array}$ & $\begin{array}{c}29.42 \\
( \pm 4.81)\end{array}$ & 0.378 & $\begin{array}{c}29.61 \\
( \pm 5.50)\end{array}$ & $\begin{array}{c}29.57 \\
( \pm 4.93)\end{array}$ & 0.066 \\
\hline Neuroticism & $\begin{array}{c}25.05 \\
( \pm 5.35)\end{array}$ & $\begin{array}{c}25.19 \\
( \pm 5.55)\end{array}$ & 0.150 & $\begin{array}{c}23.72 \\
( \pm 5.09)\end{array}$ & $\begin{array}{c}25.64 \\
( \pm 4.41)\end{array}$ & $2.459 *$ & $\begin{array}{c}25.12 \\
( \pm 5.43)\end{array}$ & $\begin{array}{c}24.67 \\
( \pm 4.84)\end{array}$ & 0.763 \\
\hline Openness & $\begin{array}{c}35.08 \\
( \pm 3.78)\end{array}$ & $\begin{array}{c}35.59 \\
( \pm 4.27)\end{array}$ & 0.770 & $\begin{array}{c}32.84 \\
( \pm 4.83)\end{array}$ & $\begin{array}{c}33.03 \\
( \pm 4.62)\end{array}$ & 0.239 & $\begin{array}{c}35.33 \\
( \pm 4.02)\end{array}$ & $\begin{array}{c}32.93 \\
( \pm 4.72)\end{array}$ & $4.742 * *$ \\
\hline
\end{tabular}

*Significant at $5 \%$ level ,** Significant at $1 \%$ level 
Table.5 Locale-wise comparison of mean scores $( \pm \mathrm{SD})$ of the Punjab and Tamil Nadu females across different dimensions of personality

\begin{tabular}{|c|c|c|c|c|c|c|c|c|c|}
\hline \multirow{3}{*}{$\begin{array}{c}\text { Dimensions } \\
\text { of } \\
\text { personality }\end{array}$} & \multicolumn{3}{|c|}{ Punjab females $\left(n_{1}=75\right)$} & \multicolumn{3}{|c|}{ Tamil Nadu females $\left(n_{2}=75\right)$} & \multicolumn{3}{|c|}{ Total $(\mathbf{n}=\mathbf{1 5 0})$} \\
\hline & Rural & Urban & $\begin{array}{c}\text { t- } \\
\text { value }\end{array}$ & Rural & Urban & $\begin{array}{c}\text { t- } \\
\text { value }\end{array}$ & $\begin{array}{l}\text { Punjab } \\
\text { females }\end{array}$ & $\begin{array}{c}\text { TN } \\
\text { females }\end{array}$ & t- value \\
\hline & mean $( \pm \mathrm{SD})$ & mean $( \pm \mathrm{SD})$ & & $\begin{array}{l}\text { mean } \\
( \pm \mathrm{SD})\end{array}$ & $\begin{array}{l}\text { mean } \\
( \pm \mathrm{SD})\end{array}$ & & $\begin{array}{l}\text { mean } \\
( \pm \mathrm{SD})\end{array}$ & $\begin{array}{l}\text { mean } \\
( \pm \mathrm{SD})\end{array}$ & \\
\hline Extraversion & $27.74( \pm 5.19)$ & $26.28( \pm 4.90)$ & 1.782 & $\begin{array}{c}25.15 \\
( \pm 3.93)\end{array}$ & $\begin{array}{c}25.87 \\
( \pm 4.88)\end{array}$ & 0.988 & $\begin{array}{c}26.96 \\
( \pm 5.05)\end{array}$ & $\begin{array}{c}25.43 \\
( \pm 4.31)\end{array}$ & $2.812 * *$ \\
\hline Agreeableness & $33.29( \pm 4.00)$ & $34.38( \pm 4.35)$ & 1.595 & $\begin{array}{c}31.70 \\
( \pm 4.72)\end{array}$ & $\begin{array}{c}32.80 \\
( \pm 6.14)\end{array}$ & 1.235 & $\begin{array}{c}33.87 \\
( \pm 4.20)\end{array}$ & $\begin{array}{c}32.13 \\
( \pm 5.31)\end{array}$ & $3.136 * *$ \\
\hline Conscientiousness & $30.46( \pm 4.50)$ & $28.55( \pm 5.82)$ & $2.244^{*}$ & $\begin{array}{c}29.98 \\
( \pm 4.76)\end{array}$ & $\begin{array}{c}29.33 \\
( \pm 5.57)\end{array}$ & 0.762 & $\begin{array}{c}29.44 \\
( \pm 5.30)\end{array}$ & $\begin{array}{c}29.72 \\
( \pm 5.07)\end{array}$ & 0.474 \\
\hline Neuroticism & $25.37( \pm 4.24)$ & $24.78( \pm 6.20)$ & 0.688 & $\begin{array}{c}23.70 \\
( \pm 5.16)\end{array}$ & $\begin{array}{c}23.77 \\
( \pm 5.06)\end{array}$ & 0.085 & $\begin{array}{c}25.05 \\
( \pm 5.35)\end{array}$ & $\begin{array}{c}23.72 \\
( \pm 5.09)\end{array}$ & $2.205 *$ \\
\hline Openness & $35.57( \pm 3.38)$ & $34.65( \pm 4.09)$ & 1.505 & $\begin{array}{c}32.26 \\
( \pm 4.80)\end{array}$ & $\begin{array}{c}33.73 \\
( \pm 4.82)\end{array}$ & 1.874 & $\begin{array}{c}35.08 \\
( \pm 3.78)\end{array}$ & $\begin{array}{c}32.84 \\
( \pm 4.83)\end{array}$ & $4.468 * *$ \\
\hline
\end{tabular}

*Significant at $5 \%$ level,$* *$ Significant at $1 \%$ level 
Table.6 Locale-wise comparison of mean scores $( \pm \mathrm{SD})$ of the Punjab and Tamil Nadu males across different dimensions of personality

\begin{tabular}{|c|c|c|c|c|c|c|c|c|c|}
\hline \multirow{3}{*}{$\begin{array}{c}\text { Dimensions } \\
\text { of } \\
\text { personality }\end{array}$} & \multicolumn{3}{|c|}{ Punjab males $\left(n_{1}=75\right)$} & \multicolumn{3}{|c|}{ Tamil Nadu males $\left(n_{2}=75\right)$} & \multicolumn{3}{|c|}{ Total $(n=150)$} \\
\hline & \multirow{2}{*}{$\begin{array}{c}\text { Rural } \\
\text { mean (土SD) }\end{array}$} & \multirow{2}{*}{$\begin{array}{c}\text { Urban } \\
\text { mean }( \pm \mathrm{SD})\end{array}$} & \multirow[t]{2}{*}{$\begin{array}{c}\text { t- } \\
\text { value }\end{array}$} & \multirow{2}{*}{$\begin{array}{l}\text { Rural } \\
\text { mean } \\
( \pm \text { SD) }\end{array}$} & \multirow{2}{*}{$\begin{array}{l}\text { Urban } \\
\text { mean } \\
\text { ( } \pm \text { SD) }\end{array}$} & \multirow{2}{*}{$\begin{array}{c}\text { t- } \\
\text { value }\end{array}$} & \multirow{2}{*}{$\begin{array}{c}\begin{array}{c}\text { Punjab } \\
\text { males }\end{array} \\
\text { mean } \\
( \pm \text { SD })\end{array}$} & \multirow{2}{*}{$\begin{array}{c}\text { TN } \\
\text { males } \\
\text { mean } \\
( \pm \mathrm{SD})\end{array}$} & \multirow[t]{2}{*}{ t- value } \\
\hline & & & & & & & & & \\
\hline Extraversion & $28.07( \pm 5.22)$ & $26.85( \pm 4.49)$ & 1.535 & $\begin{array}{c}26.86 \\
( \pm 3.71)\end{array}$ & $\begin{array}{c}25.46 \\
( \pm 3.82)\end{array}$ & $2.268^{*}$ & $\begin{array}{c}27.32 \\
( \pm 4.79)\end{array}$ & $\begin{array}{c}26.12 \\
( \pm 3.81)\end{array}$ & $2.398 *$ \\
\hline Agreeableness & $33.90( \pm 3.76)$ & $33.52( \pm 4.28)$ & 0.570 & $\begin{array}{c}30.69 \\
( \pm 5.22) \\
\end{array}$ & $\begin{array}{c}30.72 \\
( \pm 6.32)\end{array}$ & 0.034 & $\begin{array}{c}33.67 \\
( \pm 4.06)\end{array}$ & $\begin{array}{c}30.70 \\
( \pm 5.79)\end{array}$ & $5.134 * *$ \\
\hline Conscientiousness & $31.00( \pm 5.78)$ & $29.02( \pm 5.61)$ & $2.127 *$ & $\begin{array}{c}29.37 \\
( \pm 4.80)\end{array}$ & $\begin{array}{c}29.46 \\
( \pm 4.88)\end{array}$ & 0.114 & $\begin{array}{c}29.79 \\
( \pm 5.72)\end{array}$ & $\begin{array}{c}29.42 \\
( \pm 4.81)\end{array}$ & 0.603 \\
\hline Neuroticism & $24.69( \pm 5.83)$ & $25.50( \pm 5.41)$ & 0.883 & $\begin{array}{c}25.29 \\
( \pm 3.95)\end{array}$ & $\begin{array}{c}25.95 \\
( \pm 4.81)\end{array}$ & 0.923 & $\begin{array}{c}25.19 \\
( \pm 5.55)\end{array}$ & $\begin{array}{c}25.64 \\
( \pm 4.41)\end{array}$ & 0.775 \\
\hline Openness & $35.83( \pm 3.34)$ & $35.43( \pm 4.79)$ & 0.583 & $\begin{array}{c}33.09 \\
( \pm 3.97)\end{array}$ & $\begin{array}{c}32.97 \\
( \pm 5.19)\end{array}$ & 0.148 & $\begin{array}{c}35.59 \\
( \pm 4.27)\end{array}$ & $\begin{array}{c}33.03 \\
( \pm 4.62)\end{array}$ & $4.984 * *$ \\
\hline
\end{tabular}

*Significant at 5\% level , ** Significant at $1 \%$ level 
Fig.1 Locale-wise gender differences in the mean scores of the respondents across different dimensions of personality

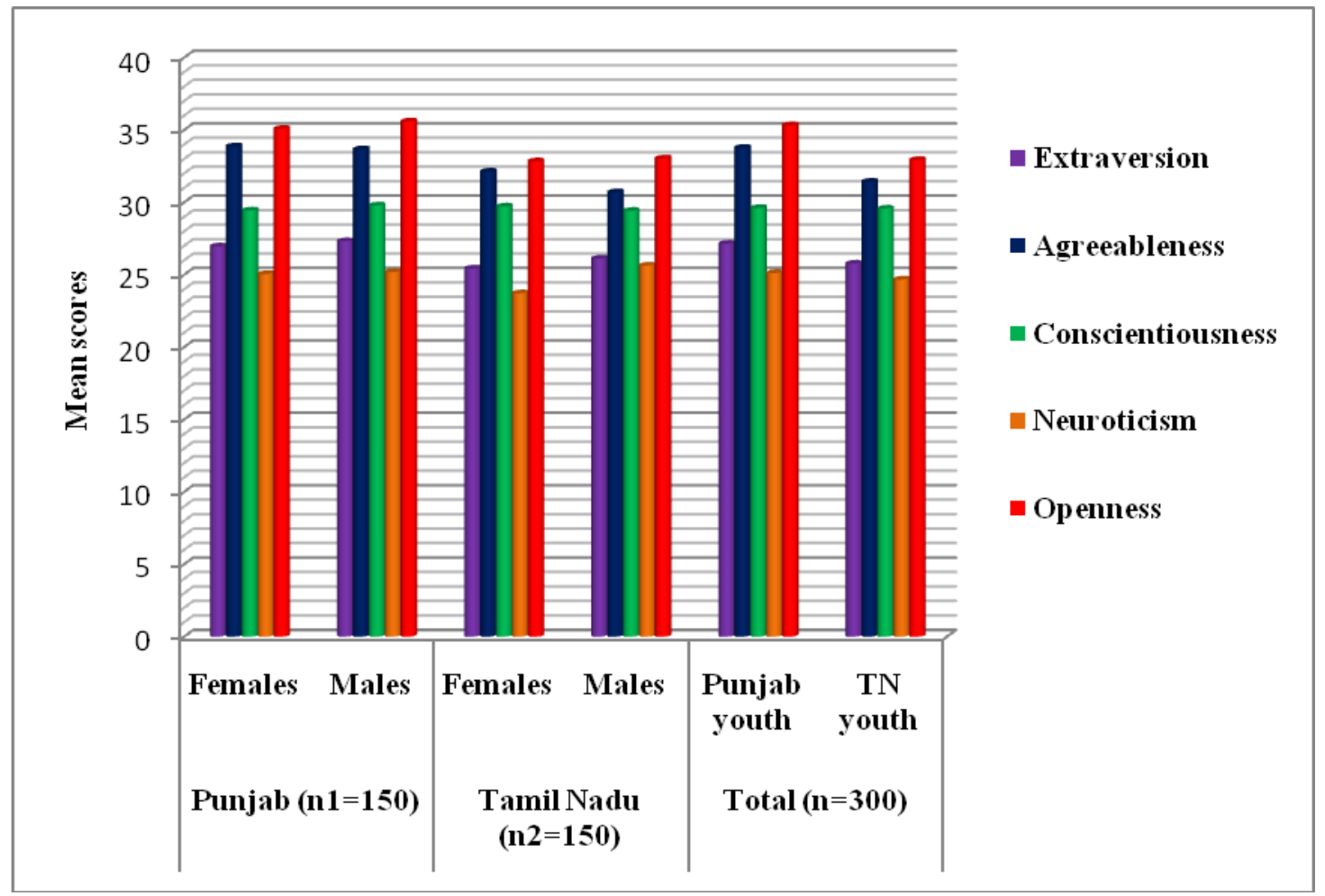

Fig.2 Locale-wise comparison of mean scores of the Punjab and Tamil Nadu females across different dimensions of personality

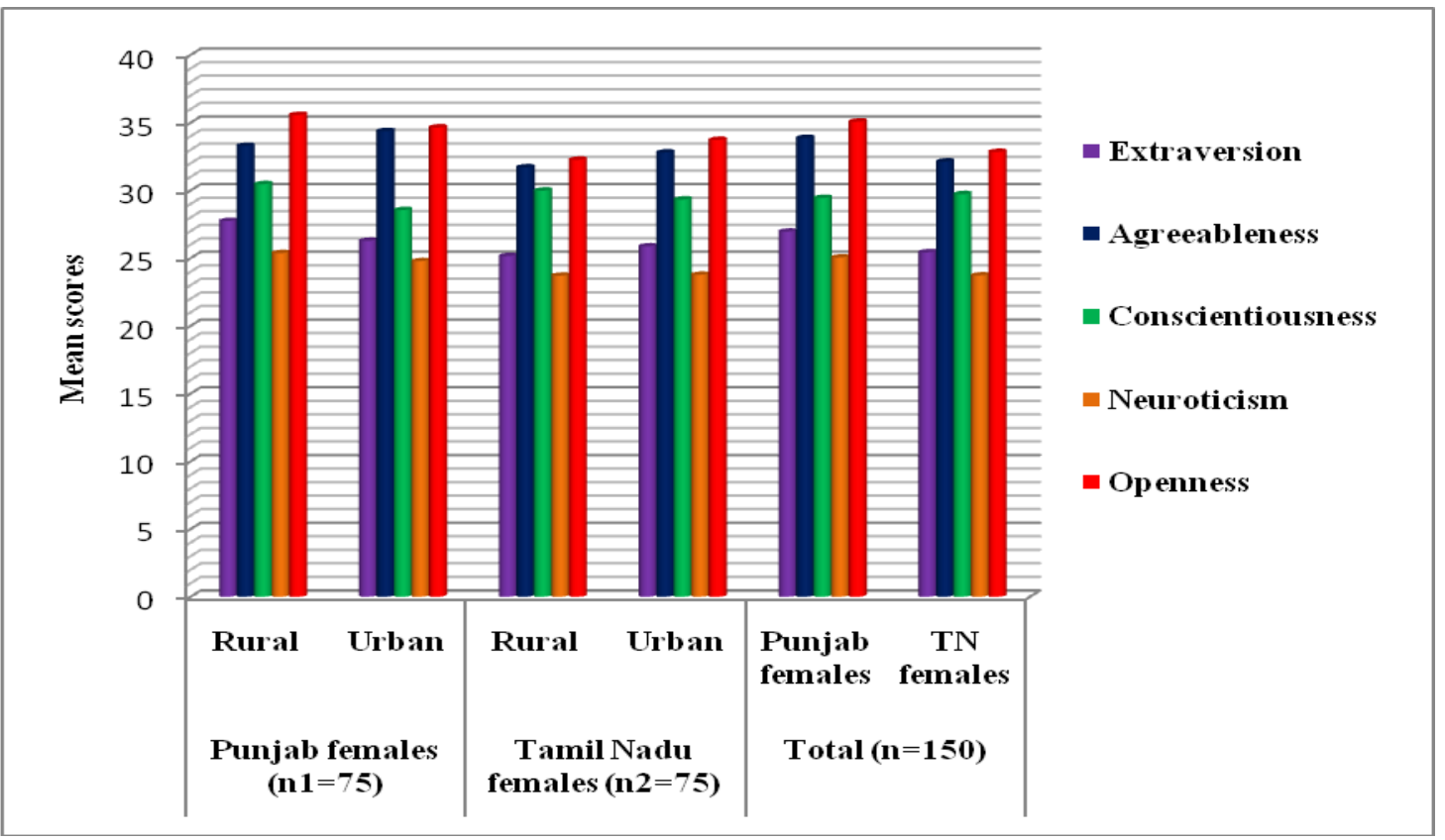


Fig.3 Locale-wise comparison of mean scores of the Punjab and Tamil Nadu males across different dimensions of personality

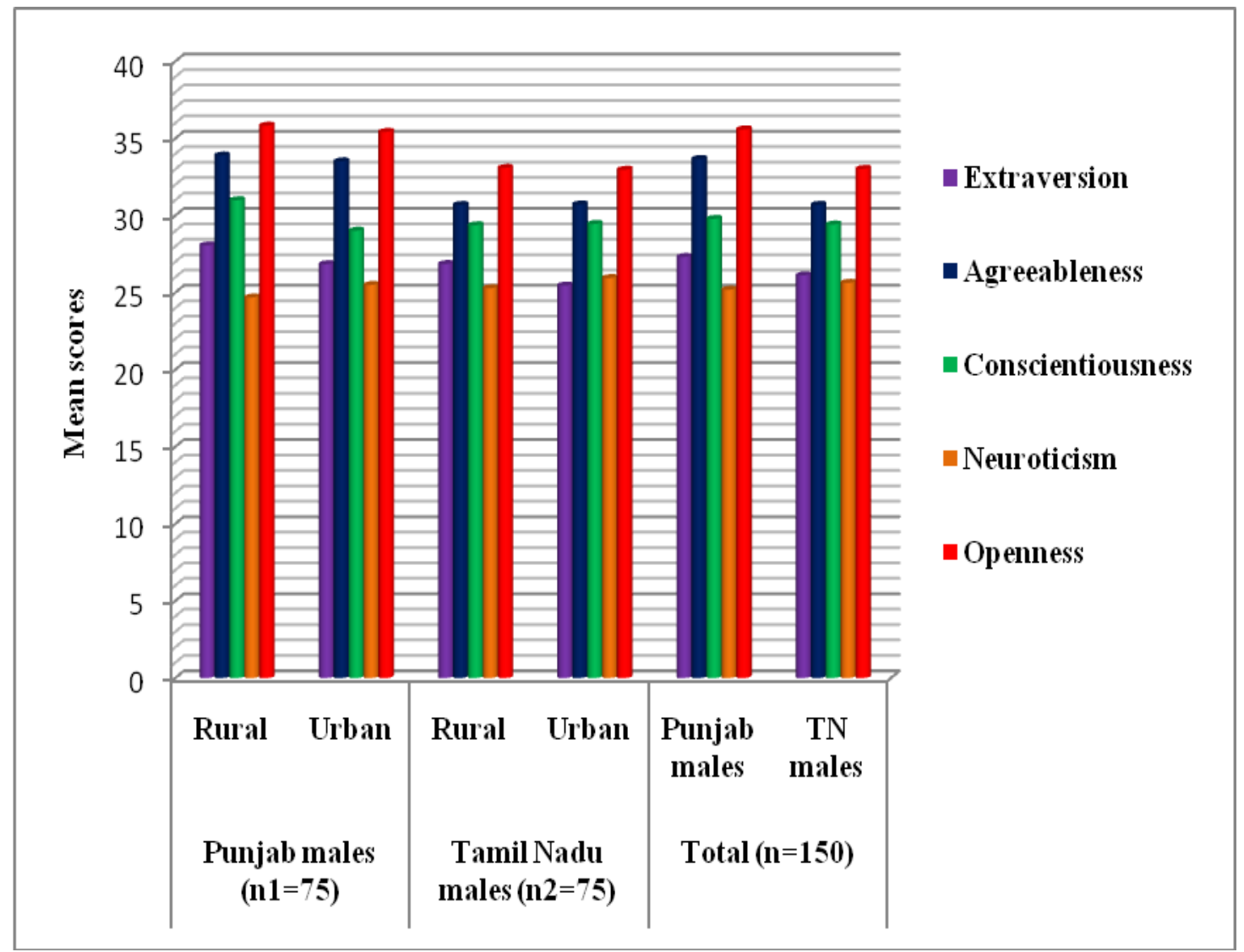

Locale-wise comparison of mean scores $( \pm$ SD) of the Punjab and Tamil Nadu males across different dimensions of personality

Table 6 exhibited the locale-wise distribution of mean scores $( \pm \mathrm{SD})$ of the Punjab and Tamil Nadu males across different dimensions of personality. Significantly better scores were found to be in Punjab rural males for conscientiousness dimension of personality. Whereas, Tamil Nadu rural males had significantly better scores in extraversion dimension. Other dimensions of both settings had non-significant differences in general. Respective total sample shows significantly better scores in extraversion, agreeableness and openness dimensions among Punjab males.

\section{References}

Allport and Odbert (1936) Trait-names: A psycho-lexical study. Psychological Monographs 47: 1-171.

Allport G W (1955) Becoming; basic considerations for a psychology of personality, Vol. 20. Yale University Press.

American Psychological Association (1981). Council of Representatives, Ethical principles of psychologists. Amer Psychol 36: 633-38.

Bem and Allen (1974) On predicting some of the people some of the time: The search for cross-situational consistencies in behaviour. Psychol Rev 81: 506-20.

Blocher D H (1974) Developmental Counseling. $2^{\text {nd }}$ ed. Ronald Press, 
Oxford, England.

Bono and Judge (2004) Personality and Transformational and Transactional Leadership: A Meta-Analysis. J Appl Psychol 89: 901-10.

Boundless P (2016). The Role of Attention in Memory. Retrieved fromtextbook/memory8/step-1-memoryencoding-54/the-role-of-attention-inmemory-215-12750

Costa and McCrae (1992) Normal personality assessment in clinical practice: The NEO Personality Inventory. Psychol Assess 4: 5-13.

Depue and Collins (1999) Neurobiology of the structure of personality: Dopamine, facilitation of incentive motivation, and extraversion. Behav Brain Sci 22: 491569.

DeYoung C G (2010) Personality neuroscience and the biology of traits. Soc Personal Psychol Compass 4:116580.

Digman and Takemoto-Chock (1981) Factors in the natural language of personality: Re-analysis, comparison, and interpretation of six major studies. Multiv Behav Res 16: 149-70.

Fleeson W and Gallagher P (2009) The implications of Big Five standing for the distribution of trait manifestation in behavior: Fifteen experience-sampling studies and a meta-analysis. J Personal Soc Psychol 97:1097.

Freud S (1964) An outline of psychoanalysis, the standard edition of the complete psychological works of Sigmund Freud. The Hogarth Press and the Institute of Psychoanalysis, London.

Funder (2006) Towards a resolution of the personality triad: Persons, situations, and behaviours. J Res Personal 40: 2134.

Funder D C, Furr R M and Colvin C R (2000) The Riverside Behavioral Q-sort: A tool for the description of social behavior. $J$
Personal 68: 451-89.

Goldberg (1993) The structure of phenotypic personality traits. Amer Psychol 48: 2634.

Gray J R (2004) Integration of emotion and cognitive control. Current Directions in Psychological Science 13: 46-48.

Graziano W G and Tobin R M (2002) Agreeableness: Dimension of personality or social desirability artifact? J Personal 70: 695-728.

John O P and Srivastava S (1999) The big five trait taxonomy history, measurement and theoretical perspectives. In Pevin L A and John O P (ed), Handbook Personal: Theory Res 2: 102-38.

John O P, Naumann L P and Soto C J (2008) Paradigm shift to the integrative big five trait taxonomy. Handbook Personal: Theory Res 3:114-58.

Judge T A, Heller D and Mount M K (2002) Five-Factor Model of Personality and Job Satisfaction: A Meta-Analysis. $J$ Appl Psychol 87:530-41.

McAdams D P and Pals J L (2006) A new Big Five: fundamental principles for an integrative science of personality. Amer Psychol 61: 204.

McCrae and John (1992) An Introduction to the Five-Factor Model and Its Applications. J of Personality60: 175215.

McCrae R R and Costa P T Jr (1985) Updating Norman's "adequate taxonomy": Intelligence and personality dimensions in natural language and in questionnaires. J Personal Soc Psychol 49: 710-21.

McCrae R R and Costa P T Jr (1999) A FiveFactor theory of personality. In L A Pervin and O P John (Eds.), Handbook of Personality: Theory and Research Pp: 139-53. Guilford Press, New York, US.

McLeod S A (2014) Sampling methods. 
Retrieved from https://www.simply psychology. org/sampling.html

Mischel and Shoda (1995) A cognitiveaffective system theory of personality: Reconceptualizing situations, dispositions, dynamics, and invariance in personality structure. Psychol Rev 102: 246- 68.

Oxford Advanced Learner's Dictionary of Current English (2010). Hornby A S, Turnbull J, Lea D, Parkinson D, Phillips $\mathrm{P}$ and Ashby M. International Student's Edition.

PytlikZillig L M, Hemenover S and Dienstbier R A (2002) What Do We Assess When We Assess a Big 5 Trait? A Content Analysis of the Affective, Behavioural, and Cognitive Processes Represented in Big 5 Personality
Inventories. Personal Soc Psychol Bulletin 28: 847-58

Rice F P (1981) The adolescent: development, relationship and culture. Allyn and Bacon, USA.

Roberts B W (2006) Personality Development and Organizational Behavior. Res Organizational Behavior 27:1-40.

Sarah M S (2012) Behaviourist Theories of Personality. Retrieved Jun 21, 2019 from Explorable.com: https://explorable.com/behaviouristtheories-of-personality.

Tellegen (1982) The structure of mood change: An idiographic/homothetic analysis. $J$ of Personality and Social Psychol., 43: 111-22.

\section{How to cite this article:}

Sundharalingam Balasubramani and Tejpreet K. Kang. 2020. Comparative Study of Personality among Youth in Punjab and Tamil nadu. Int.J.Curr.Microbiol.App.Sci. 9(01): 868-883. doi: https://doi.org/10.20546/ijcmas.2020.901.097 